\title{
AN UPDATED PHYTOCHEMICAL AND PHARMACOLOGICAL REVIEW ON GYNURA PROCUMBENS
}

\begin{abstract}
KAMRAN ASHRAF ${ }^{1,2 *}$
${ }^{1}$ Department of Pharmacology and Chemistry, Faculty of Pharmacy, Universiti Teknologi MARA, Puncak Alam Campus, Bandar Puncak Alam, Selangor Darul Ehsan, Malaysia. ${ }^{2}$ Atta-ur-Rahman Institute for Natural Products Discovery (AuRIns), Universiti Teknologi MARA, Puncak Alam Campus, Bandar Puncak Alam, Selangor Darul Ehsan, Malaysia. E-mail: kamranashraf2@gmail.com
\end{abstract}

Received: 08 August 2018, Revised and Accepted: 29 October 2018

ABSTRACT

Nowadays, the use of medicinal plants increased significantly for the aim of producing more effective drugs with fewer side effects. Gynura procumbens (family Asteraceae) is a high value medicinal plant with different properties that are considered less, regardless of having great therapeutic potential in traditional medicine. Many pharmacological studies have established the ability of this plant to exhibit antimicrobial, antioxidant, hepatoprotection, antigenotoxic, antiplasmodial, cytotoxic, cardioactive, antidiabetic, anti-inflammatory, etc. The aim of this study was to review the updated phytochemical, pharmacological investigations as well as the traditional and therapeutic uses of $G$. procumbens. Important and different experimental data have been addressed along with a review of most of the phytochemicals identified in this plant.

Keywords: Gynura procumbens, Medicinal plant, Phytochemical, Pharmacological.

(C) 2019 The Authors. Published by Innovare Academic Sciences Pvt Ltd. This is an open access article under the CC BY license (http://creativecommons. org/licenses/by/4. 0/) DOI: http://dx.doi.org/10.22159/ajpcr.2019.v12i4.28996

\section{INTRODUCTION}

Gynura procumbens belongs to family Asteraceae is a fast growing evergreen herb. In Malay, G. procumbens is called Sambung nyawa which means "prolongation of life" whereas, in Chinese, it is called Bai Bing Cao which means "100 ailments" [1]. Other than G. procumbens, it is also known as longevity spinach. This green plant is called longevity spinach because it is like heaven on earth, with tons of health benefits concealed in this plant [2]. G. procumbens falls under the kingdom Plantae, which represents plants. It comes from the phylum of Tracheophyta, which comprising plants with a vascular system. It is classified under the class Magnoliopsida, which is a valid botanical name for a class of flowering plants [2]. It is a small plant that can grow up to a height of approximately $\sim 1-3 \mathrm{~m}$, with a fleshy stem and purple tint. The leaves of $G$. procumbens are ovate-elliptic or lanceolate, with $3.5-8 \mathrm{~cm}$ long and $0.8-3.5 \mathrm{~cm}$ wide and the flowering heads are panicled, narrow, yellow, and 1-1.5 cm long [3]. The plant is a bicolor herbal species due to green and red color variation [4]. The plants are commonly found in tropical Asia countries such as China, Thailand, Indonesia, Malaysia, and Vietnam [5]. In Malaysia, the fresh leaves of G. procumbens are commonly eaten raw with food, and in Thailand, the leaves are used for cooking [6]. G. procumbens also could be used as an appetizer to enhance the desire to eat when taken with food [7]. The leaves of G. procumbens can be consumed safely in diet due to not having toxic effects [1]. G. procumbens is a species of plant that usually used in medication. It is commonly used as a safe alternative to chemical-based medicine because it could give a lot of benefit to the human body. They are generally used in many different countries for the treatment purpose such as to treat kidney discomfort, rheumatism, diabetes mellitus, as wound healing, constipation, and hypertension. It seems to possess the high therapeutic pharmacological potential to treat various diseases [5].

\section{Chemical constituents in G. procumbens}

G. procumbens is a valuable plant that contains various chemical constituents that show excellent therapeutic effects. The leaves contain important active chemical constituents such as flavonoids, saponins, tannins, terpenoids, and sterol glycosides [8]. It contains several constituents including kaempferol, quercetin, kaempferol-3-0- $\beta$-Dglucopyranoside, kaempferol-3-0-rutinoside, rutin, chlorogenic acid and 3,5-dicaffeoilquinate methyl ester, terpenoid, tannin, alkaloid, saponin, and astragalinin (Fig. 1) [7,9].

In the past several studies researchers have discovered many valuable information. In an experiment, G. procumbens leaves were extracted using a variety of solvents. It was reported that non-polar or less polar compounds were fractionated by a non-polar solvent such as chloroform, while ethyl acetate as a polar solvent was used to fractionate polar compounds such as phenolics, flavonoids, and glycosides. Four types of solvent were used for extraction which is ethanol fraction (EF), chloroform fraction (CF), ethyl acetate fraction (EAF), and n-butanol fraction (BF). The results showed that rutin, quercetin, and kaempferol were found in all fractions, whereas myricetin and apigenin were not detected in chloroform and BF [10]. It was also seen that fractionation of $G$. procumbens with ethyl acetate, exhibit 2 times higher content of rutin, myricetin, quercetin, and apigenin than ethanol extract and the amounts of myricetin and quercetin were slightly increased. Wan et al. [11] also supported this statement and reported that all individual flavonoids were found to be dominant in the EAF except for kaempferol, which was found to be the most predominant flavonoid in the EF.

Kaewseejan et al. [6] also identified five phenolic acids in hydroxybenzoic acids (HBA) phenol, of ethanolic fraction and EAF which are gallic acid, protocatechuic acid, HBA, vanillic acid, and syringic acid. However, vanillic acid was not detected in $\mathrm{CF}$ and $\mathrm{BF}$, whereas protocatechuic acid and HBA were detected in all fractions except for CF. For hydroxycinnamic acid (HCA) phenol, four phenolic acids, including caffeic acid, p-coumaric acid, ferulic acid, and sinapic acid were detected in all the fractions except in CF. Syringic acid and p-coumaric acid were not found in chloroform. In another study, Jegadeeswari et al. [12] reported higher antioxidant activity of HCA than HBA. The presence of a $\mathrm{CH} \mathrm{CHCOOH}$ group in the HCA derivatives, which is more active than the $\mathrm{COOH}$ group in HBA derivatives, leads to the greater antioxidant activity.

Rosidah et al. [13] conducted an experiment and generated HPTLC profiles chromatograms of methanol extract, EAF, and butanol fraction. Solvent system was ethyl acetate: methanol:water (100:13.5:10) (v/v). Detection was done at $365 \mathrm{~nm}$ and $254 \mathrm{~nm}$. Results showed that 


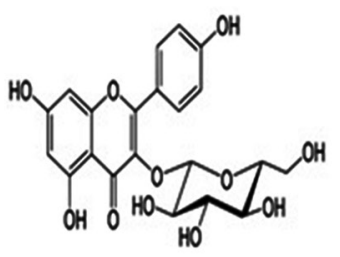

kaempferol-3-0-glucoside<smiles>O=c1c(O)c(-c2ccc(O)c(O)c2)oc2cc(O)cc(O)c12</smiles>

Quercetin

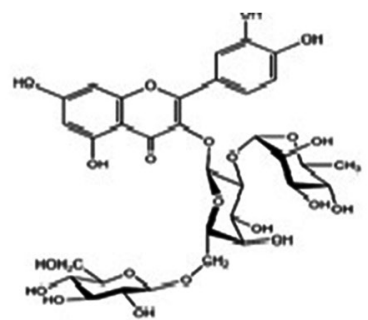

Quercetin 3-0-rhamnosyl-(1-6)-galactoside

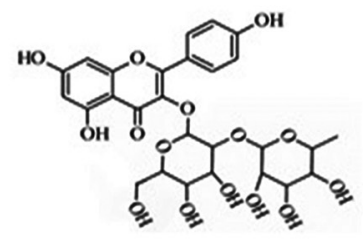

Kaempferol-3-0-rutinoside

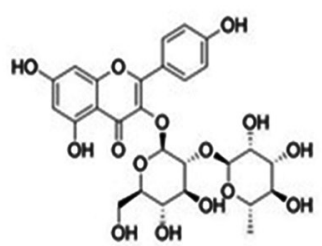

kaempferol-3-0-neohesperidoside

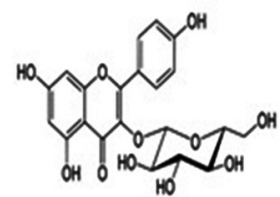

Astragalin<smiles>O=C(O)C1C=C(O)C(O)C(O)C1</smiles>

Gallic acid

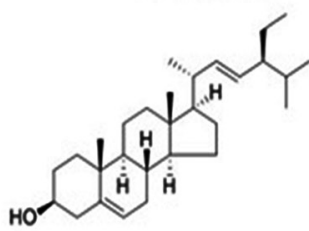

Stigmasterol

Myricetin

Fig. 1: Some of the important chemical constituents found in G. procumbens

kaempferol-3-0-rutinoside and astragalin are the most representative phenolic compounds in $\mathrm{EF}$ and $\mathrm{BF}$ fraction. Kim et al. [10] identified kaempferol-3-0-rutinoside, quercetin-3-Orutinosida, and isobioquercetin compounds in ethanolic extract on the TLC plate.

In another experiment, optimization of total flavonoid compound extraction from Gynura medica leaf was investigated using response surface methodology. In this experiment high performance liquid chromatography - diode array detection (DAD)- electrospray ionization - mass spectrometry (MS) system and solvent for the mobile phase was water $-0.1 \%$ acetic acid $(\mathrm{A})$ and acetonitrile $(\mathrm{B})$ were used. The gradient elution was 0-30 min, linear gradient $10-30 \% \mathrm{~B} ; 30-45 \mathrm{~min}$, and linear gradient $30-60 \%$ B. The flow rate was $0.8 \mathrm{~mL} / \mathrm{min}$ and the column was operated at $30^{\circ} \mathrm{C}$. Peaks were detected with the DAD at $347 \mathrm{~nm}$. Seven peaks of flavonoid compounds were separated and identified by the MS value coupled with the ultraviolet spectrum data [14].

The Fourier-transform infrared spectra of polysaccharide samples were studied by Choi et al. [15]. Based on the studies, they stated that the broad and intense absorption peak around $3439 \mathrm{~cm}-1$ was attributed to the $\mathrm{OH}$ stretching vibration, and the weak band near $2936 \mathrm{~cm}^{-1}$ was due to the stretching vibration of $\mathrm{CH}$ including $\mathrm{CH}, \mathrm{CH} 2$, and $\mathrm{CH} 3$ in the sugar ring. He justified that these two absorption bands were both belonged to the characteristic functional groups of polysaccharides. The absorption peak at approximately $1405 \mathrm{~cm}^{-1}$ could be attributed to the deforming vibration of the $\mathrm{CH}$ bond. In addition, Saiman et al. [16] studied the leaf explants-derived adventitious root culture as an alternative culture system for G. procumbens biomass containing bio-active compounds and then analyzed the metabolite content in the root culture of $G$. procumbens using proton nuclear magnetic resonance based profiling technique.

\section{PHARMACOLOGICAL ACTIVITIES OF G. PROCUMBENS}

G. procumbens is a potential natural source of compounds with various pharmacological actions which can be utilized for the development of novel therapeutic agents. Hence, a lot of scientists had done a further experiment to validate and provide scientific evidence for the therapeutic claims of its efficacy. G. procumbens is a plant that exhibits a lot of medicinal effect to treat a variety of health ailments such as kidney discomfort, rheumatism, diabetes mellitus, constipation, and hypertension [5]. This makes it as a target for pharmacological studies aiming to validate and provide scientific evidence for the traditional claims of its efficacy.

\section{Antihypertensive and cardioprotective activity}

Hoe et al. [17] found that G. procumbens could be used to prevent hypertension as it has been reported to result in significant lowering of systolic blood pressure and mean arterial pressure in hypertensive rats. Basic mechanisms regulating blood pressure are control of blood vessel diameter, heart rate, contractility, and regulation of blood volume. In an experiment, G. procumbens extract gives pressure-lowering effect by inhibit the angiotensin-converting enzyme activity. G. procumbens antagonizes the vasoconstrictive effect of Ang II by activate the nitric oxide and prostaglandin release [18]. Poh et al. [19] revealed that $G$. procumbens extract can also result in a significant decrease in heart rate by creating strong negative chronotropic, and negative ionotropic effects on atrium [9]. The chemical constituents present in G. procumbens can inhibit calcium influx in the muscles of the blood vessels. Due to the absence of calcium, the muscles of blood vessels relax and blood pressure lowers [17].

\section{Antihyperglycemic activity}

Diabetes had been reported as one of the common diseases that might affect people. In general, speaking, diabetes occurs due to low levels of insulin in the body, which leads to high glucose levels in the blood. Many patients are reluctant to use pharmacological drugs due to the possible side effect. So by introducing $G$. procumbens herbal therapies to the patient, we could reduce the occurrence and risk of diabetes. A study was conducted to determine the anti-diabetic and pro-fertility effect 
of $G$. procumbens on streptozotocin-induced male rats within 14 days and showed that aqueous extract of $G$. procumbens has a pro-fertility effect and possess anti-hyperglycemic activity [19,20]. Hamid et al. [21] investigated the effect of $G$. procumbens treatment on insulin level. Results showed the stimulatory effect of insulin-secreting cell lines by G. procumbens extract. However, it showed no effect when exposure to clonal pancreatic cells [22]. On a further experiment, however, no significant change has been noticed in plasma insulin level in diabetic rats treated with the extracts, suggesting that the hypoglycemic activity of $G$. procumbens does not rely on insulin tropic activity but may instead be due to its extra-pancreatic effect [23].

In another experiment, treatment with $G$. procumbens stimulated glucose uptake on 3T3 adipocytes. In addition, an improvement of activity was seen in the presence of insulin [24]. In another, in vivo, experiment also confirmed an enhanced uptake of glucose by muscle tissue of diabetic rats. The results showed the direct effect of $G$. procumbens extract on glucose uptake [25]. Synergistic effect with stronger hypoglycemic effect was also observed when $G$. procumbens was used together with Azadirachta indica or Andrographis paniculata [26]. The synergistic effect is assumed to be associated with the varied range of active compounds present in the extract combination. This indication suggests the presence of bioactive principles which possess insulin mimetic properties in G. procumbens [27].

\section{Anticancer}

Cancer is a global disease which severely effects the human population. Medicinal plants continue to provide discovery of new drugs that could be major leads against various pharmacological targets, particularly in cancer diseases. Approximately about $80 \%$ decrease in azoxymethaneinduced aberrant crypt foci in rats preventing colon cancer when treated with ethanolic extract of $G$. procumbens [28]. It also inhibits the initial phase of carcinogenesis. Ethanolic extract of $G$. procumbens triggered a significant decrease in expression and activity of cytochrome P450 enzymes such as CYP3A4, CYP1A2, and CYP1A1 that may lead to drop in the conversion of the respective procarcinogens to cancer triggers [29].

In general, the blockade of angiogenesis pathways will result in inhibition of growth, invasion, and metastasis of tumor cells [30]. G. procumbens was shown to exhibit antiangiogenic activity as the treatment caused inhibition in the expression of vascular endothelial growth factor and prevented the formation of new blood vessels on fertilized chicken eggs $[31,32]$. Based on the reported studies, G. procumbens appears to be an effective chemotherapeutic agent against a wide range of cancer cell types, and it exerts its anticancer activities through the modulation of various points of carcinogenesis including cancer initiation, cell proliferation, metastasis, and angiogenesis. Cotreatment studies of $G$. procumbens and chemotherapy drugs also have been carried and reported good results. In an experiment, cotreatment of $G$. procumbens with other drugs such as doxorubicin or 5-fluorouracil lead to strong synergistic effect against breast and colon cancer cells [33-35]. However, in other cases, it showed an antagonistic effect when cotreatment of $G$. procumbens extract with cisplatin and failed to further suppress cancer cell proliferation [36]. In a recent experiment, extract of methanol, ethanol, and ethyl acetate were tested on U-87 cell line by MTT-based anti-proliferative assay. Results showed the high anti-proliferative effect on U-87 cell line of the methanol extracts of G. procumbens [37].

\section{Antimicrobial activity}

The antimicrobial activity of ethanolic extract of aerial plant parts has been established to show virucidal and antireplicative activity against herpes simplex virus HSV-1 and HSV-2. This was confirmed in a clinical trial on patients with persistent herpes labialis where treatment with G. procumbens herbal gels reduced the number of patients infected with HSV. G. procumbens extract also exhibits chemo-suppression effects toward malarial parasite strains of Plasmodium falciparum 3D7 and Plasmodium berghei NK65 [38]. Other experiment showed that G. procumbens extract also used for antifungal activity against fungi such as Candida albicans and Aspergillus niger. The results showed evidence that validates the traditional use of $G$. procumbens in the treatment of infections by pathogens such as herpes simplex virus and malaria parasites $[39,40]$. The antiplasmodial activity of $G$. procumbens was also reported by Vejanan et al. [41].

\section{Anti-inflammatory}

G. procumbens is a folk medicine and has excellent anti-inflammatory activity [42]. When the ethanolic extract is tested, it showed significant dermal healing signs, less scar width, and considerable faster healing rate when compared with the control group treated with saline [43]. In an experiment, immunomodulatory activity of $G$. procumbens was tested using mice splenic cells. Ethanolic extract of $G$. procumbens at dose 0.1 and $1.0 \mu \mathrm{g} / \mathrm{mL}$ caused greater proliferation of CD4+CD25+, CD4+CD62L-, CD4+CD62L+, CD8+CD62L-, and CD8+CD62L+ T cells but lower proliferation of B220+ cells when compared to the higher dosage at $10 \mu \mathrm{g} / \mathrm{mL}$. However, at dosage of $10 \mu \mathrm{g} / \mathrm{mL}$, it was shown to promote high proliferation of B cells. These results have demonstrated that the concentration used in the experiment is the determining factor for whether $G$. procumbens acts as an immune stimulator immune suppressant $[44,45]$.

\section{Wound healing enhancement activity}

Topical application of $G$. procumbens extract significantly accelerated the rate of wound healing, by increase regulation of collagen expression and promote angiogenesis $[43,46]$. Studies showed that antioxidants could play a significant role in the wound healing process and can be an important contributory factor in the wound healing property [47]. Antioxidants have been reported to show a significant role in the wound healing process and expressively improve wound healing and protect tissues from oxidative damage $[48,49]$. G. procumbens contain a wide array of free radical scavenging molecules and flavonoids were the major naturally occurring antioxidant components in this plant [50]. According to Akowuah et al. [51] flavonoids present in G. procumbens may be responsible for wound-healing activity because it lessens lipid peroxidation and promotes the strength of collagen fibers.

\section{Antioxidant activity}

The study showed that $G$. procumbens has excellent antioxidant property. In an experiment, different extracts of $G$. procumbens were assessed through DPPH assay to measure its free radical scavenging ability $[52,53]$. The ethanolic extract of $G$. procumbens exhibited the highest percentage of DPPH inhibition among different types of the extracts [54]. There are several antioxidant assays including ferric reducing assay, Trolox equivalent, $\beta$-carotene - linoleic acid, and xanthine oxidase inhibitory assays confirm the antioxidant property of $G$. procumbens [55]. Meanwhile, lipid peroxidation is a common result of oxidative stress, the antioxidative effect of $G$. procumbens was exposed when it inhibited lipid peroxidation with the median effective concentration of $2.75 \mathrm{mg} / \mathrm{mL}$ [56,57]. In addition, the administration of methanol extract before oxidative stress induction was able to reverse the elevation of plasma lipid peroxidation in tested animals [51]. Krishnan et al. [58] revealed that the root extract has the highest antioxidant activity when compared to the other parts of the plant.

\section{Organ protective effect}

Previous research on $G$. procumbens also showed gastroprotective effect. Mahmood et al. [46] reported that administration of the ethanolic extract significantly lessened the areas of ethanol-induced gastric ulcer in rats; with a reduction of submucosal edema and infiltration of leukocytes. This finding has intrigued the researchers to further explore the protective effect of $G$. procumbens. In another study on skin damage, the antiphotoaging property of $G$. procumbens has been tested and was found to cause a significant inhibition in the expression of matrix metalloproteinases induced by ultraviolet irradiation in human dermal fibroflasts [10]. The results obtained could be associated with ROS scavenging activity of $G$. procumbens [46]. The details of most of the pharmacological activities of $G$. procumbens have shown in Table 1. A similar type of study and data collection was also done in previous research papers [64-67]. 
Table 1: Important pharmacological activities of G. procumbens

\begin{tabular}{|c|c|c|c|}
\hline Activity & Type of extract & Mode of action & References \\
\hline \multirow[t]{4}{*}{$\begin{array}{l}\text { Antihypertensive } \\
\text { and cardioprotective }\end{array}$} & $\begin{array}{l}\text { Methanolic leaf extract } \\
\text { (Butanol fractions and subfractions) }\end{array}$ & $\begin{array}{l}\text { It causes anti contraction activity on the left atrium by } \\
\text { promoting relaxation. }\end{array}$ & [9] \\
\hline & Ethanolic leaf extract (Butanol fraction) & $\begin{array}{l}\text { It decreases mean arterial pressure and also decrease in } \\
\text { heart rate in rats. }\end{array}$ & {$[27]$} \\
\hline & Ethanolic leaf extract (Aqueous fraction) & $\begin{array}{l}\text { It reduces contraction of rat aorticring by AngI and AngII. } \\
\text { Potentiation of vasorelaxant effect and blood pressure } \\
\text { dropping effect of bradykinin in vivo. }\end{array}$ & [19] \\
\hline & Ethanolic leaf extract (aqueous) & $\begin{array}{l}\text { It causes vasorelaxation of isolated aorta, negative } \\
\text { ionotropic effects in the left atrium, negative chronotropic } \\
\text { effect in right atrium. }\end{array}$ & [18] \\
\hline \multirow[t]{9}{*}{ Anticancer } & Ethanolic leaf extract & $\begin{array}{l}\text { It showed decreased total of azoxymethane induced } \\
\text { aberrant in rats. }\end{array}$ & [28] \\
\hline & Ethanolic leaf extract & It acts as repressed tumor incidence in DMBA treated rats. & [58] \\
\hline & Ethanolic leaf extract & $\begin{array}{l}\text { It causes as anti-proliferative effect on liver cells of rats } \\
\text { prompted by DMBA. }\end{array}$ & [59] \\
\hline & Ethanolic leaf extract & $\begin{array}{l}\text { It acts to reduce the proliferation of mammary gland } \\
\text { epithelial cells. }\end{array}$ & {$[60]$} \\
\hline & Ethanolic leaf extract & $\begin{array}{l}\text { It shows decreased DMBA-induced breast cancer } \\
\text { development in rats. }\end{array}$ & [33] \\
\hline & Ethanolic leaf extract & $\begin{array}{l}\text { It causes blockade of VEGF receptor through inhibition of } \\
\text { COX-2, tyrosine kinase, and MMP activity. }\end{array}$ & {$[32]$} \\
\hline & Ethanolic leaf extract & $\begin{array}{l}\text { It reduces COX-1activity, tyrosine kinase, and MMP } \\
\text { activity. }\end{array}$ & {$[30]$} \\
\hline & Ethanolic leaf extract (ethyl acetate fraction) & $\begin{array}{l}\text { It acts to inhibit colon cancer cells proliferation and } \\
\text { potentiated efficacy of 5-FUbutantagonism effect with } \\
\text { cisplastin. }\end{array}$ & {$[34]$} \\
\hline & Ethanolic leaf extract & Chick CAM embryo: Inhibition of angiogenesis & [31] \\
\hline \multirow[t]{4}{*}{ Anti-inflammatory } & Ethanolic leaf extract & $\mathrm{T}$ cells: Increased proliferation & [43] \\
\hline & & B cells: Decreased proliferation. & \\
\hline & Ethanolic leaf extract & It causes to increase in $\mathrm{T}$ cells proliferation. & [42] \\
\hline & Ethanolic leaf extract & $\begin{array}{l}\text { It enhanced wound healing rate: Less inflammatory cells } \\
\text { at granulation tissue, more collagen with angiogenesis. }\end{array}$ & [41] \\
\hline \multirow{4}{*}{ Antihyperglycemic } & $\begin{array}{l}\text { Ethanolic leaf extract (Ethyl acetate, } \\
\text { n-butanol, aqueous) }\end{array}$ & It lowers fasting blood glucose levels indiabetic rats. & {$[62]$} \\
\hline & Ethanolic leaf extract & $\begin{array}{l}\text { It causes fasting of blood glucose levels reduced in } \\
\text { diabetic rats. }\end{array}$ & [63] \\
\hline & Ethanolic leaf extract & $\begin{array}{l}\text { Blood glucose level gets reduced; improve pancreatic islet } \\
\text { condition, increased insulin expression. }\end{array}$ & [26] \\
\hline & Methanolic leaf extract and butanol fraction & Fasting blood glucose levels get reduced indiabetic rats. & {$[64]$} \\
\hline \multirow[t]{3}{*}{ Antimicrobial } & $\begin{array}{l}\text { Dichloromethane, ethyl acetate fraction leaf } \\
\text { extract }\end{array}$ & $\begin{array}{l}\text { Antibacterial activity against Gram-positive and } \\
\text { Gram-negative bacteria, antifungal activity. }\end{array}$ & [3] \\
\hline & Ethanolic leaf extract and Aqueous extract & $\begin{array}{l}\text { Destroying growth of malarial parasites and upsurge } \\
\text { survival time of infected mice. }\end{array}$ & [39] \\
\hline & Aerial ethanolic extract & $\begin{array}{l}\text { Virucidal action againstHSV-1 and HSV-2, reduced } \\
\text { infection of HSV } 1 \text { in clinical trial patients with recurrent } \\
\text { herpes labialis. }\end{array}$ & [36] \\
\hline
\end{tabular}

ACE: Angiotensin converting enzyme, DMBA: 7,12-dimethylbenz (a) anthracene, VEGF: Vascular endothelial growth factor, COX-2: Cyclooxygenase-2,

CAM: Chorioallantoic membrane, PDH: Pyruvate dehydrogenase, G. procumbens: Gynura procumbens

\section{CONCLUSIONS}

Herbal medicines have been used for various illnesses for many centuries. Due to better availability, affordable cost, and fewer side effects, they have immense potential. G. procumbens is one of the many species that are still left unexplored despite knowing the various medicinal values of this plant. G. procumbens can help prevent chronic disease or optimize health, therefore, reducing health-care costs and improving the quality of life. A study on this plant which is being consumed is only an approach of "drug rediscovery." In view of all the above facts, G. procumbens should be extensively explored with modern scientific approaches to identify its nutritional effects. The plant $G$. procumbens has the potential to develop a drug against various diseases.

\section{ACKNOWLEDGMENT}

Kamran Ashraf would like to acknowledge Universiti Teknologi MARA for the financial support under the reference number 600-IRMI/MyRA 5/3/LESTARI (079/2017).

\section{AUTHOR CONTRIBUTION}

Kamran Ashraf participates in data collection, drafting and revising it critically for important intellectual content.

\section{CONFLICTS OF INTEREST}

The author have none to declared. 


\section{REFERENCES}

1. Yam MF, Sadikun A, Asmawi MZ, Rosidah. Antioxidant potential of Gynura procumbens. Pharm Biol 2008;46:616-25.

2. Keng CL, Yee LS, Pin PL. Micropropagation of Gynura procumbens (Lour.) Merr. An important medicinal plant. J Med Plants 2009;3:105-11.

3. Rahman AF, Asad MS. Chemical and biological investigations of the leaves of Gynura procumbens. Int J Biosci 2013;3:36-43.

4. Abidin ZZ, Mohamad WN, Samad M. Optimization of chlorophyll extraction from Gynura procumbens. Malays J Anal Sci 2016;6:1421-8.

5. Tan HL, Chan KG, Pusparajah P, Lee LH, Goh BH. Gynura procumbens: An overview of the biological activities. Front Pharmacol 2016;7:52.

6. Kaewseejan N, Sutthikhum V, Siriamornpun S. Potential of Gynura procumbens Leaves as source of flavonoid-enriched fractions with enhanced antioxidant capacity. J Funct Foods 2015;12:120-8

7. Saeed MA, Meng K, Sadikun A, Murugaiyah V, Asmawi M, Ismail Z. Stability study of Gynura procumbens extracts using high performance liquid chromatography. J Pharm Res 2014;8:822-7.

8. Hoe SZ, Lee CN, Mok SL, Kamaruddin MY, Lam SK. Gynura procumbens Merr. Decreases blood pressure in rats by vasodilatation via inhibition of calcium channels. Clinics 2011;66:143-50.

9. Abrika OS, Yam MF, Asmawi MZ, Sadikun A, Dieng H, Hussain EA, et al. Effects of extracts and fractions of Gynura procumbens on rat atrial contraction. J Acupunct Meridian Stud 2013;6:199-207.

10. Kim J, Lee CW, Kim EK, Lee SJ, Park NH, Kim HS, et al. Inhibition effect of Gynura procumbens extract on UV-B-induced matrix-metalloproteinase expression in human dermal fibroblasts. J Ethnopharmcol 2013;137:427-33.

11. Wan $\mathrm{C}, \mathrm{Yu} \mathrm{Y}$, Zhou S, Tian S, Cao S. Isolation and identification of phenolic compounds from Gynura divaricata Leaves. Pharmacogn Mag 2011;7:101-8.

12. Jegadeeswari P, Daffodil ED, Mohan VR. Quantification of total phenolics, flavonoid and in vitro antioxidant activity of Aristolochia bracteata Retz. Int J Pharm Pharm Sci 2014;6:747-52.

13. Rosidah, Yam MF, Sadikun A, Ahmad M, Akowuah GA, Asmawi MZ, et al. Toxicology evaluation of standardized methanol extract of Gynura procumbens. J Ethnopharmacol 2009;123:244-9.

14. Liu W, Yu Y, Yang R, Wan C, Xu B, Cao S, et al. Optimization of total flavonoid compound extraction from Gynura medica Leaf using response surface methodology and chemical composition analysis. Int $\mathrm{J}$ Mol Sci 2010;11:4750-63

15. Choi SI, Park MH, Han JS. Gynura procumbens extract alleviates postprandial hyperglycemia in diabetic mice. Prev Nutr Food Sci 2016;21:181-6.

16. Saiman MZ, Mustafa NR, Schulte AE, Verpoorte R, Choi YH. Induction, characterization, and NMR-based metabolic profiling of adventitious root cultures from leaf explants of Gynura procumbens. Plant Cell Tissue Organ Cult 2012;109:465-75.

17. Hoe SZ, Lee CN, Mok SL, Kamaruddin MY, Lam SK. Gynura procumbens Merr. Decreases blood pressure in rats by vasodilatation via inhibition of calcium channels. Clinics 2011;66:143-50.

18. Kaur N, Kumar R, Yam MF, Sadikun A, Sattar AM, Asmawi MZ. Antihypertensive effect of Gynura procumbens water extract in spontaneously hypertensive rats. Int J Appl Res Nat Prod 2013;6:20-7.

19. Poh TF, Ng HK, Hoe SZ, Lam SK. Gynura procumbens causes vasodilation by inhibiting angiotensin II and enhancing bradykinin actions. J Cardiovasc Pharmacol 2013;61:378-84.

20. Akmara KK, Mahanem MN. Profertility and antidiabetic properties of Gynura procumbens on streptozotocin induced male rats. AIP Conf Proc 2016;1784:020027.

21. Hamid M, Saufi M, Musaadah NM. Study on antidiabetic properties of Gynura procumbens Merr. In 18 Seminar of the Malaysian Natural Products Society (Kota Kinabalu: Universiti Malaysia Sabah); 2004

22. Hassan Z, Ahmed M, Yosof P, Naidu S, Kumar G, Umachigi S. Hypoglycemic effect of aqueous extract of Gynura procumbens. Pharmacologyonline 2008;1:30-50.

23. Lee HW, Hakim P, Rabu A, Sani HA. Antidiabetic effect of Gynura procumbens Leaves extracts involve modulation of hepatic carbohydrate metabolism in streptozotocin-induced diabetic rats. J Med Plants Res 2012;6:796-812.

24. Bohari M, Pauliena S, Hamid M, Shaari K, Lajis N. Glucose uptake: Stimulatory activity of Gynura procumbens in 3T3-F442A adipocytes. In: Malaysian Medicinal Plant: Chemistry and Biological Activity. Sarawak: UNIMAS and Malaysian Natural Products Society; 2006.

25. Hassan Z, Yam MF, Ahmad M, Yusof AP. Antidiabetic properties and mechanism of action of Gynura procumbens water extract in streptozotocin-induced diabetic rats. Molecules 2010;15:9008-23.
26. Pramono S, Nugroho A. Effect of herbal combination of Andrographis paniculata (Burm. f) Ness and Gynura procumbens (Lour.) Merr ethanolic extracts in alloxan-induced hyperglycemic rats. Int Food Res J 2015;22:1332-7.

27. Sunarwidhi AL, Sudarsono S, Nugroho AE. Hypoglycemic effect of combination of Azadirachta indica A. Juss. and Gynura procumbens (Lour.) Merr. Ethanolic extracts standardized by rutin and quercetin in alloxan induced hyperglycemic rats. Adv Pharm Bull 2014;4:613.

28. Shwter AN, Abdullah NA, Alshawsh MA, Alsalahi A, Hajrezaei M, Almaqrami AA, et al. Chemoprevention of colonic aberrant crypt foci by Gynura procumbens in rats. J Ethnopharm 2014;151:1194-201.

29. Afandi A, Sadikun A, Ismail S. Antioxidant properties of Gynura procumbens extracts and their inhibitory effects on two major human recombinant cytochrome $\mathrm{P} 450$ s using a high throughout luminescence assay. Asian J Pharm Clin Res 2014;7:36-41.

30. Ghofur A, Hamid IS, Listyorini D. Anti-carcinogenic activity of Gynura procumbens extract through cytochrome P450 and glutathione stransferase. Int J PharmTech Res 2015;8:24-9.

31. Hamid IS, Wati WK, Mustofa I, Plumeriastuti H. Activity test of Gynura procumbens Leaves extract as antiangiogenic on chick embryo chorioallantoic membrane induced by basic fibroblast growth factor (bFGF). Vet Med 2011;4:105-10.

32. Jenie RI, Meiyanto E, Murwanti R. Antiangiogenic effect of Sambung nyawa leaves (Gynura procumbens (Lour.) Merr.) Ethanolic extract on chick embryo chorioallantoic membrane (CAM). Indones J Pharm 2006; $17: 50-5$

33. Hamid I, Dewi R, Nazar D, Ratnani H. Effectivity of Gynura procumbens extract to inhibit vascular endothelial growth factor (VEGF) expression on new blood vessels of chorioallantoismembran (CAM) chicken embryonal. Vet Med 2013;6:27-32.

34. Meiyanto E, Jenie RI. Co-chemotherapy of sambungnyawa (Gynura procumbens (Lour.) Merr.) Leaves ethanolic extract and doxorubicin on breast cancer cell. Indones J Pharm 2007;18:81-7.

35. Nurulita NA, Meiyanto E, Matsuda E, Kawaichi M. Gynura procumbens modulates the microtubules integrity and enhances distinct mechanism on doxorubicin and 5-flurouracil-induced breast cancer cell death. Orient Pharm Exp Med 2012;12:205-18.

36. Nurulita NA, Meiyanto E, Sugiyanto S, Matsuda E, Kawaichi M. The ethyl acetate fraction of Gynura procumbens sensitizes widr colon cancer cell line against 5-fluorouracil but shows antagonism with cisplatin. Int J Phytomed 2011;3:392-405.

37. Rohin MA, Jumli MN, Ridzwan N, Baig AA, Latif AZ, Hadi NA. Effects of Gynura procumbens extracts on anti-proliferative activity and its associated morphological changes of human glioblastoma multiforme cell line (U-87). Pharmacogn J 2018;10:492-6.

38. Jarikasem S, Charuwichitratana S, Siritantikorn S, Chantratita W, Iskander M, Frahm AW, et al. Antiherpetic effects of Gynura procumbens. Evid Based Comp Alt Med 2013;2013:394865.

39. Kaewseejan N, Sutthikhum V, with enhanced antioxidant capacity. J Funct Foods 2015;12:120-8.

40. Nasir NN, Khandaker MM, Mat N. Bioactive compound and therapeutic value of some Malaysia medicinal plants: A review. J Agron 2015;14:319-30

41. Vejanan V, Latip J, Chin LP, Embi N, Sidek HM. In vitro and in vivo anti-plasmodial activities of Gynura procumbens. Sains Malays 2012;41:1535-42.

42. Wiart C. Medicinal Plants of Asia and the Pacific. Boca Raton, FL: CRC Press.

43. Zahra AA, Kadir FA, Mahmood AA, Al Hadi AA, Suzy SM, Sabri SZ, et al. Acute toxicity study and wound healing potential of Gynura procumbens Leaf extract in rats. J Med Plant Res 2011;5:2551-8.

44. Dwijayanti DR, Rifa'i M. Immunomodulator testing on ethanol extract of Gynura procumbens Leaves to Mus musculus adaptive immune system: In vitro study. J Exp Life Sci 2014;4:10-4.

45. Dwijayanti DR, Riffs M. Gynura procumbens ethanolic extract promotes lymphocyte activation and regulatory $\mathrm{T}$ cell generation in vitro. J Trop Life Sci 2015;5:14-9.

46. Mahmood A, Mariod AA, Al-Bayaty F, Abdel-Wahab SI. Antiulcerogenic activity of Gynura procumbens Leaf extract against experimentally-induced gastric lesions in rats. J Med Plants Res 2010;4:685-91.

47. Habibipour S, Oswald TM, Zhang F, Joshi P, Zhou XC, Dorsett MW, et al. Effect of sodium diphenylhydantion on skin wound healing in rats. Plast Reconstr Surg 2003;112:1620-7.

48. Shukla A, Rasik AM, Dhawan BN. Asiaticoside-induced elevation of antioxidant levels in healing wounds. Phytother Res 1999;13:50-4

49. Getie M, Gebre-Mariam T, Rietz R, Neubert RH. Evaluation of the 
release profiles of flavonoids from topical formulations of the crude extract of the leaves of Dodonea viscosa (Sapindaceae). Pharmazie 2002;57:320-2.

50. Martin A. The use of antioxidants in healing. Dermatol Surg 1996;22:156-60

51. Akowuah G, Ahmad M, Fei YM. Effects of Gynura procumbens Leaf extracts on plasma lipid peroxidation and total antioxidant status in CCl4-treated rats. Nat Prod J 2012;2:247-51

52. Akowuah GA, Mariam A, Chin JH. The effect of extraction temperature on total phenols and antioxidant activity of Gynura procumbens Leaf. Pharmacogn Mag 2009;4:81-5.

53. Afandi A, Sadikun A, Ismail S. Antioxidant properties of Gynura procumbens extracts and their inhibitory effects on two major human recombinant cytochrome $\mathrm{P} 450$ s using a high throughout luminescence assay. Asian J Pharm Clin Res 2014;7:36-41.

54. Maw SS, Mon MM, OO ZK. Study on antioxidant and antitumor activities of some herbal extracts. World Acad Sci Eng Technol 2011;75:450-5

55. Rosidah, Yam M, Sadikun A, Asmawi M. Antioxidant potential of Gynura procumbens. Pharm Biol 2008;46:616-25.

56. Luerang A, Thammasarn K, Sittiwet C, Naowaratwattana W, Chaichanadee S, Puangpronpitag D, et al. Evaluation of nutritional value and antioxidative properties of the medicinal plant Gynura procumbens extract. Asian J Plant Sci 2010;9:146-51.

57. Kumar S, Pandey AK. Chemistry and biological activities of flavonoids: An overview. Sci World J 2013;2013:16.

58. Krishnan V, Ahmad S, Mahmood M. Antioxidant potential in different parts and callus of Gynura procumbens and different parts of gynura bicolor. Biomed Res Int 2015;2015:1-7.

59. Hoe SZ, Lam SK. Hypotensive activity of an aqueous fraction of Gynura procumbens and possible mechanisms of action (hypertension, basic $1(\mathrm{H})$, The $69^{\text {th }}$ annual Scientific meeting of the Japanese circulation society). Circ J 2005;69:348.

60. Gofur A, Hamid IS, Listyorini D. Gene p53 mutations after the induction of 7,12-dimethylbenz(a)anthracene (DMBA) and administration of anti-carcinogenesis properties of Gynura procumbens in sprague dawley rats. Biomed Eng 2015;1:53-7.

61. Nisa F, Hermawan A, Murwanti R, Meiyanto E. Antiproliferative effect of Gynura procumbens (lour.) Merr. Leaves etanolic extract on 7,12dimethylbenz(a)antracene induced male rat liver. Adv Pharm Bull 2012;2:99-106.

62. Hamid IS, Meiyanto E, Widyarini S. CYP1A1and GST $\mu$ expression of hepatocytes induced by 7,12-dimethylbenz(a)anthracene and the influence of ethanolic extract of Gynura procumbens. Indones J Pharm 2009;20:198-206.

63. Kang YH, Kim TW, Kim KK, Choe M. Effect of Gynura procumbens water extract on enzymes activities related with glucose metabolism in HepG2 cell. FASEB J 2015;29:730

64. Algieri K, Atangwho IJ, Meng KY, Asmawi MZ, Sadikun A, Murugaiyah V. Antihyperglycaemic and toxicological evaluations of extract and fractions of Gynura procumbens Leaves. Trop Life Sci Res 2014;25:75-93

65. Algariri K, Meng KY, Atangwho IJ, Asmawi MZ, Sadikun A, Murugaiyah V, et al. Hypoglycemic and anti-hyperglycemic study of Gynura procumbens Leaf extracts. Asian Pac J Trop Biomed 2013;3:358-66

66. Akowuah G, Sadikun A, Mariam A. Flavonoid identification and hypoglycaemic studies of the butanol fraction from Gynura procumbens. Pharm Biol 2002;40:405-10.

67. Ashraf K, Sultan S. Comprehensive review on Curcuma longa Linn.: Phytochemical, pharmacological and molecular study: A review. Int J Green Pharm 2017;11:1-15.

68. Ashraf K, Sultan S, Ali SA. Phychemistry, phytochemical, pharmacological and molecular study of Zingiber officinale Roscoe: A review. Int J Pharm Pharm Sci 2017;9:8-16.

69. Pujiyanto S, Lestari Y, Suwanto A, Budiarti S, Darusman LK. Alpha-glucosidase inhibitor activity and characterization of endophyticactinomycetes isolated from some Indonesian diabetic medicinal plants. Int J Pharm Pharm Sci 2012;4:327-33. 